\title{
Elaboration of Amorphous and Crystalline Titanium Dioxide on FTO: its Characterization and Photocatalytic Effect on Orange Methyl
}

\author{
Rahal Foudil $^{a}$ and Abdi Djamila ${ }^{b, *}$ \\ ${ }^{a}$ Laboratoire d'énergétique et d'électrochimie du solide. Département de génie des procédés, \\ Faculté de Technologie, U. F.A. Sétif 1, 19000. Algérie \\ ${ }^{b}$ Laboratoire d'énergétique et d'électrochimie du solide. Département de chimie, Faculté des \\ Sciences, U. F.A. Sétif 1, 19000. Algérie
}

Received March 14, 2018; accepted May 10, 2018

\begin{abstract}
In this paper, we report on the preparation of an amorphous and nanocrystalline structure of titanium dioxide, by cathodic electrodeposition on fluorine doped tin dioxide (FTO) coated glass, from an aqueous peroxo-titanium complex solution. Structural X-ray analysis shows anatase phase for heated deposits, and an amorphous form for non-heated deposits. Scanning electron microscopy (SEM) allowed investigating the morphological aspect of the deposits which exhibited nano-particulate grain size. AFM results exhibited the different roughness values of both kinds of films. The crystalline deposits have been used as catalysts for the photocatalytic oxidation of methyl orange dye, under an irradiation source (UV lamp of $365 \mathrm{~nm}$ ). The results revealed that the dye has undergone a slight degradation under UV illumination. Using spectrophotometer measurements, the decolourisation rate was estimated from residual concentration.
\end{abstract}

Keywords: titanium dioxide; electrodeposition; nanostructures; photocatalytic oxidation, methyl orange dye.

\section{Introduction}

Nanostructured semiconductor materials have been the prime focus of scientific research, due to their unusual optical, chemical, photo electrochemical and electronic properties. Since several years, nanocrystalline titanium dioxide $\left(\mathrm{TiO}_{2}\right)$ is one of the most investigated oxide materials, due to its important applications in environmental cleanup, hydrophilic coating, gas sensors and dye-sensitized solar cell DSSC [1-3].

It is also used in photocatalytic processes, because, compared to other semiconductors, it is chemical and biologically inert, photocatalytically stable,

\footnotetext{
* Corresponding author. E-mail address:naimadjam@hotmail.com
} 
relatively easy to produce, able to efficiently catalyze reactions, cheap, and without risks to the environment [4].

Dyes are widely used in many industries. Some of them are non-biodegradable, and have to be eliminated before being released into natural water streams. Studies have proven that most of them are toxic [5-6], and it is difficult to remove them from the water environment, as they are designed to be resistant to physical, chemical and microbial fading [7]. However, as common wastewater treatments are not always effective, one of the new alternative biodegradation treatments consists of $\mathrm{TiO}_{2}$, which has the photocatalytic ability to cut down organic compounds [8-11]. Colorants degradation in visible light or under artificial illumination using $\mathrm{TiO}_{2}$ has been earlier reported by Chatterjee and Mahata [12], and by a number of researchers who dealt with heterogeneous dye photocatalytic decomposition [13-16]. Wang investigated $\mathrm{MeO}$ photocatalytic degradation with other commercial dyes in $\mathrm{TiO}_{2}$ suspension, under solar light [17]. In fact, photo catalysis can be determined as a photo induced reaction that is accelerated by the presence of a catalyst (semiconductor), in which reactions are activated by the absorption of an energy photon (equal to or higher than the band-gap energy (Ebg) of the catalyst). The absorption leads to a charge separation, due to the promotion of an electron $\left(\mathrm{e}^{-}\right)$from the semiconductor catalyst's valence band to the conduction band, thus generating a hole $\left(\mathrm{h}^{+}\right)$. In order to favor the photo catalyst reaction, the recombination of the electron and the hole must be prevented as much as possible, leading the transfer of the activated electron to the oxidant, and producing a reduced product.

The research described by this paper included: the preparation of amorphous and crystalline titanium dioxide films on FTO, by electrodeposition, after cathodic deposition optimization; the study of their structural characterization by XRD, and of their morphological aspects by SEM and AFM; and the application and testing of their ability as catalysts under illumination, for methyl orange dye photocatalytic oxidation, under an irradiation source (UV lamp of $365 \mathrm{~nm}$ ).

\section{Experimental}

\section{Materials and instruments}

Analytical grade chemicals of titanium salt $\left(\mathrm{TiOSO}_{4}\right)$ and peroxide $\left(\mathrm{H}_{2} \mathrm{O}_{2}\right)$ were purchased from Sigma-Aldrich; potassium nitrate $\left(\mathrm{KNO}_{3}\right)$ and nitric acid $\left(\mathrm{HNO}_{3}\right)$ are Biochem products.

Methyl orange (MeO) was obtained from Sigma Chemie GmbH (Germany), and used without further purification. $\mathrm{MeO}$ structure is $\mathrm{C}_{14} \mathrm{H}_{14} \mathrm{~N}_{3} \mathrm{SO}_{3} \mathrm{Na}$.

The photo catalyst used in this work was $\mathrm{TiO}_{2}$ crystalline films obtained after heat-treatment, to give them a better active surface. All deposits were prepared in a small three electrode cell. Optically transparent fluorine-tin-oxide coated

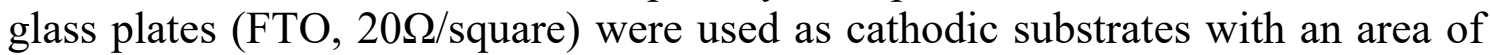
$1.5 \mathrm{~cm}^{2}$. A Pt plate $(20 \times 10 \times 1 \mathrm{~mm})$ was used as counter electrode and saturated $\mathrm{Ag} / \mathrm{AgCl}$ as reference electrode. A Voltalab 340 potentiostat was employed. Prior to the film deposition, FTO substrates were sequentially cleaned in acetone, propanol and water, each one for $5 \mathrm{~min}$, and, finally, the substrate was etched in 
$45 \% \mathrm{HNO}_{3}$, for 2 min. FTO was used as a substrate for many reasons: it behaves as a TCO (transparent conductive oxide), thanks to its conductivity; $\mathrm{TiO}_{2}$ electrodeposition may be easily done; its high degree of transparency facilitates catalysts' optical absorption measurements and favors the deposits' optical properties investigation and their UV-Vis behavior before and after illumination, and it also permits both front and back-side illumination for the study of photo electrodes. Titanium dioxide films were cathodically electrodeposited from an aqueous peroxo-titanium solution. The deposition bath was mixed in a $\mathrm{KNO}_{3}: \mathrm{TiOSO}_{4}: \mathrm{H}_{2} \mathrm{O}_{2}=1: 0.2: 0.3$ ratio, and with an amount of $\mathrm{HNO}_{3}$, to adjust the $\mathrm{pH}$ at 1.4. The bath temperature was maintained at $20^{\circ} \mathrm{C} . \mathrm{H}_{2} \mathrm{O}_{2}$ acts as generator of $\mathrm{OH}^{-}$, responsible for the increase in local $\mathrm{pH}$ that will react with $\mathrm{Ti}^{4+}$, to give titanium hydroxide on FTO.

Cathodic electrodeposition was carried out between $0 \mathrm{mV}$ and $-1.4 \mathrm{mV}$ (versus saturated $\mathrm{Ag} / \mathrm{AgCl}$ ), which led to the formation of a $\mathrm{TiO}(\mathrm{OH})_{2} \cdot \mathrm{xH}_{2} \mathrm{O}$ gel film on FTO. Subsequently, some films were subjected to heat-treatment in air, for 1 hour, at $450{ }^{\circ} \mathrm{C}$, to obtain a crystalline titanium dioxide thin film [18]. The phenomenon of precipitation during $\mathrm{TiO} 2$ electrodeposition is a well-known problem for $\mathrm{pH}$ values greater than 2 ; however, the right precursor concentration and $\mathrm{pH}$ adjustment to a lower value, up to 1.4, allowed to avoid the precipitation, and, thus, the deposition only occurred at the surface.

The crystallization behavior of the fresh and heat-treated electrodeposited titanium dioxide films was analyzed at room temperature by X-ray diffraction (XRD), using a PHILIPS X'PERT diffractometer with $\mathrm{Cu} \mathrm{K} \alpha$ radiation, and a $2 \theta$ scan rate of $0.01 \%$ s. The surface morphological features of the films were observed using a LEO 982 scanning electron microscope (SEM). Images of the films were obtained using atomic force microscopic (AFM), and the scans were made on areas of the films with $1 \mu \mathrm{m} \times 1 \mu \mathrm{m}$.

\section{Absorbance measurements}

The absorbances of dye solutions, before and after degradation, were measured at different degradation times, under a UV light irradiation source. Measurements were carried out using a UV-1800 SHIMADZU UV-vis spectrophotometer and a UV-Probe software for the curves' analysis. The percentage of degradation was calculated from the following equation:

$$
\text { Degradation } \%=\left[1-\mathrm{A}_{\mathrm{o}} / \mathrm{A}_{\mathrm{t}}\right] \times 100
$$

where $A_{t}$ is the absorbance after time $(t)$ and $A_{o}$ is the dye initial concentration before degradation.

\section{Results and discussion}

\section{Structural and morphological characterization}

Fig. 1 ( $a$ and $b$ ) shows X-ray diffraction (XRD) of titanium dioxide films, as deposited and annealed at $450{ }^{\circ} \mathrm{C}$. Pattern a and b (Fig. 1) show the characteristics peaks of the as-deposited film and of the film heated at $450{ }^{\circ} \mathrm{C}$, for 
1 hour, in air. The as-deposited film was found to be amorphous, as indicated by the absence of any diffraction peaks. Such results have been reported by [19-21], and a faint broad peak at about $2 \theta=25$ was observed. The heat-treated film at $450{ }^{\circ} \mathrm{C}$ confirms the formation of an anatase structure of $\mathrm{TiO}_{2}$; the sharp peak detected at 25.77 can be attributed to its anatase phase, according to [22-24]. The peaks indexed with an asterisk are related to the FTO substrate; the related JCPDS-file number is (21-1272).
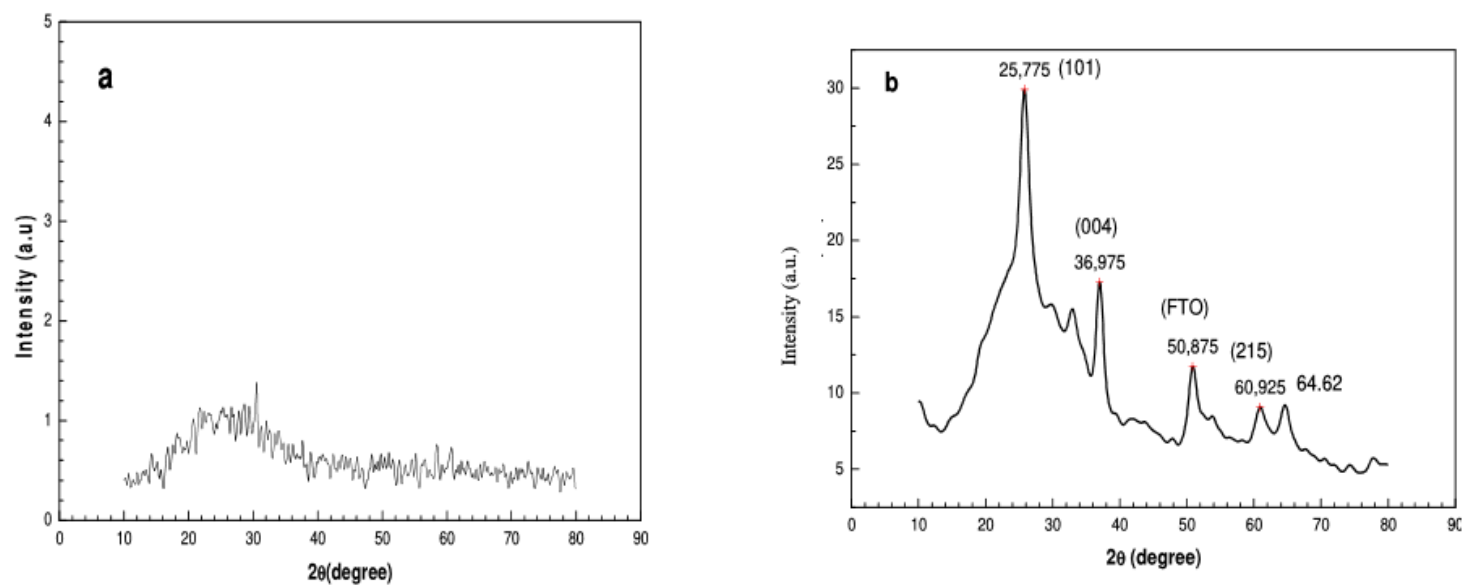

Figure 1. XRD patterns of titanium dioxide films: a) as-deposited and b) annealed at $450^{\circ} \mathrm{C}$.

The average crystallite sizes of titanium dioxide deposits were estimated from the $\mathrm{X}$-ray line broadening analysis by the Debye-Sherrer's equation:

$$
\left(d=\frac{0.9 \hat{k}}{\beta \cos \theta}\right)
$$

where $\theta$ is the Bragg angle, $\lambda=1.542 \AA$ is the wavelength of the $\mathrm{X}$-ray radiation and $\beta$ is full width at half maximum (FWHM). The calculation based on the peak at $2 \theta=25.775$ gave a value of $4.9 \mathrm{~nm}$, which shows the nanoscale range of the grains.

Fig. 2 shows scanning electron microscopy (SEM) images of as-deposited (Fig 2a) and heat-treated films, at $450{ }^{\circ} \mathrm{C}$, for 1 hour (Fig. 2b). It exhibits distinguished spherical morphology, and confirms the formation of nano particulate and nanoporous films. The as-deposited film is quite homogenous, clearly indicating that the particles are roughly spherical, and it shows areas richer in crystallites. Some cracks were observed on the heat-treated titanium dioxide, which was attributed to the film dehydration when subjected to heattreatment, accordingly to the reaction:

$$
\mathrm{TiO}(\mathrm{OH})_{2} \cdot \mathrm{xH}_{2} \mathrm{O}
$$

$$
\mathrm{TiO}_{2}+(\mathrm{x}+1) \mathrm{H}_{2} \mathrm{O}
$$

They are similar to those produced by [25-29]. 

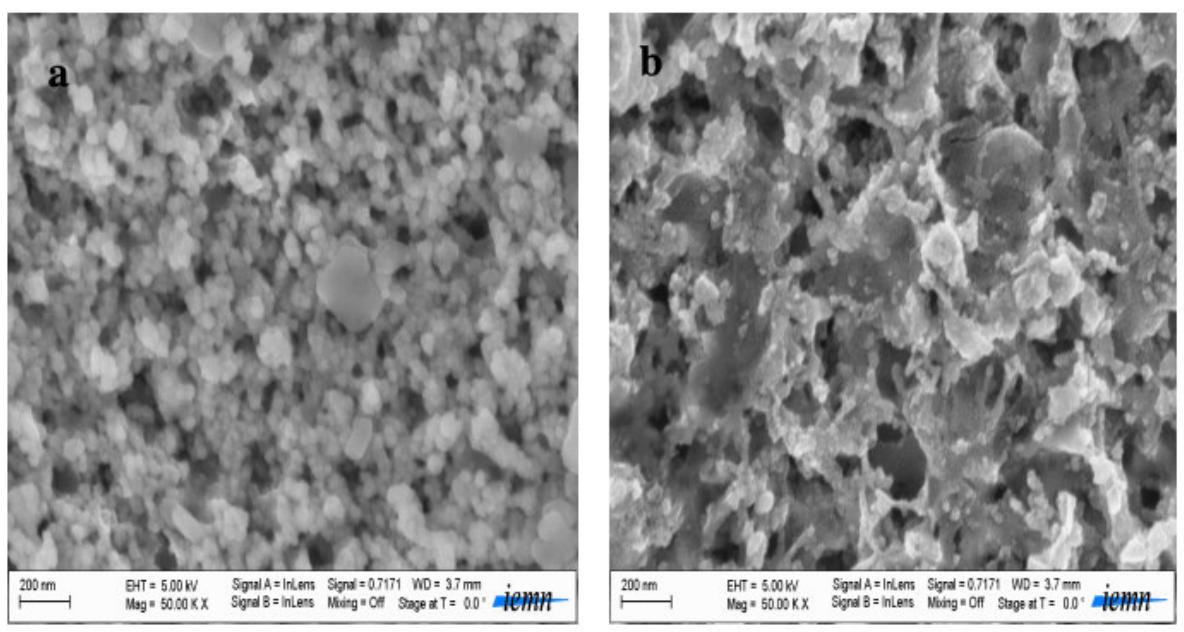

Figure 2. SEM micrographs of titanium dioxide films a) as-deposited and b) heattreated at $450{ }^{\circ} \mathrm{C}$, for 1 hour.

AFM technique was used to investigate surface morphology and topographic relief of our deposits. Figs. 3a and b show the AFM top-view of two-dimensional thin surface plots $\mathrm{TiO}_{2}$ films, as-deposited and annealed, at $450{ }^{\circ} \mathrm{C}$, for 1 hour, respectively. The surface morphology and roughness of the two films show the main differences between both deposits. Careful examinations of the images show that the heat-treatment at $450{ }^{\circ} \mathrm{C}$ produced changes in the surface topography. The AFM image of the as-deposited titanium dioxide (Fig. 3a) indicates the formation of a rough surface, and the mean square roughness value is $8.81 \mathrm{~nm}$. The appearance of the annealed film AFM image (Fig. 3b) seems to be quite similar to the as-deposited film, and the mean square roughness value decreased $(6.79 \mathrm{~nm})$, which was probably due to the formation of particles aggregates by heat-treatment. Such observations agree with our SEM pictures and XRD calculation peak size, and they are in accordance with previous studies [30-31].
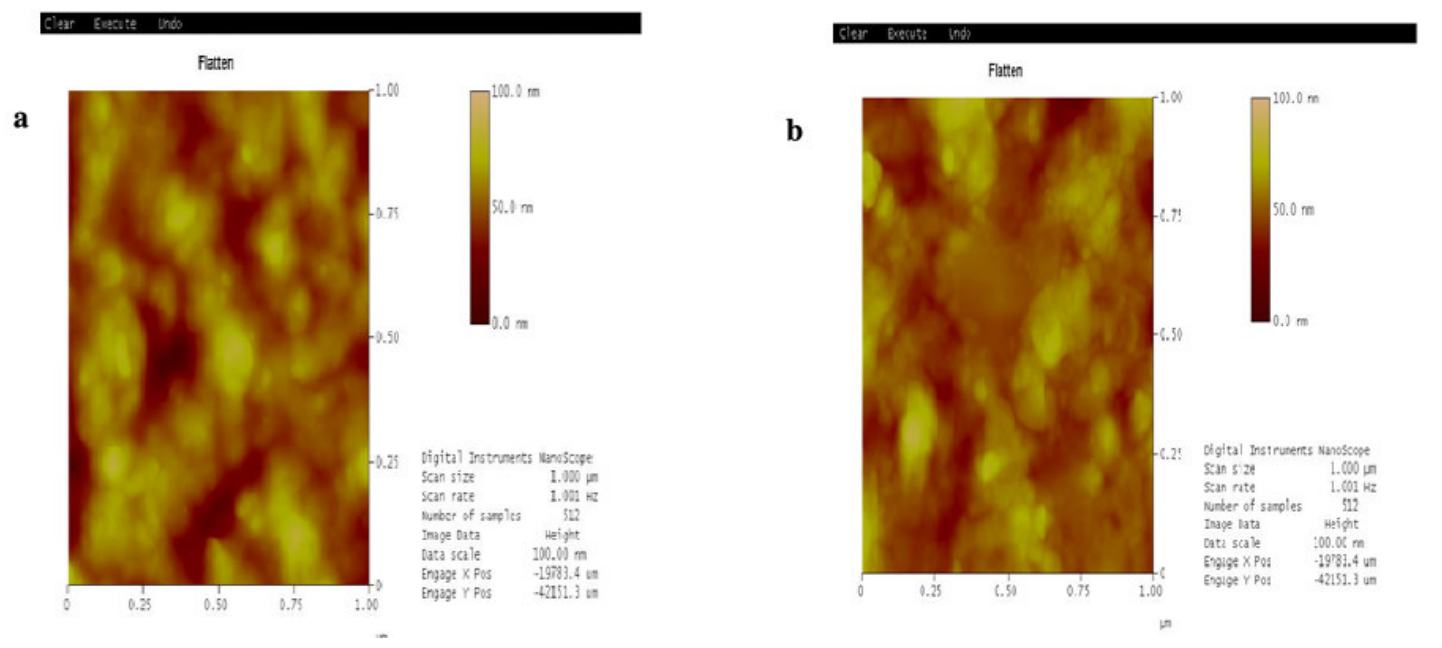

Figure 3. AFM images of two-dimensional relief of titanium dioxide films: a) asdeposited and b) heat treated at $450{ }^{\circ} \mathrm{C}$, for 1 hour. 


\section{Electrochemical characterization}

The electrochemical characterization of the titanium dioxide thin films on asdeposited (crystalline) and sintered FTO, at $450{ }^{\circ} \mathrm{C}$, for one hour, in the air (amorphous), was carried out by a fast scan rate $(100 \mathrm{mV} / \mathrm{s})$ cyclic voltamperometry experiment, in order to establish the electrode active surface area of the titanium dioxide electrode in a $0.1 \mathrm{M} \mathrm{K}_{2} \mathrm{SO}_{4}$ solution Fig. 4 (a and b).
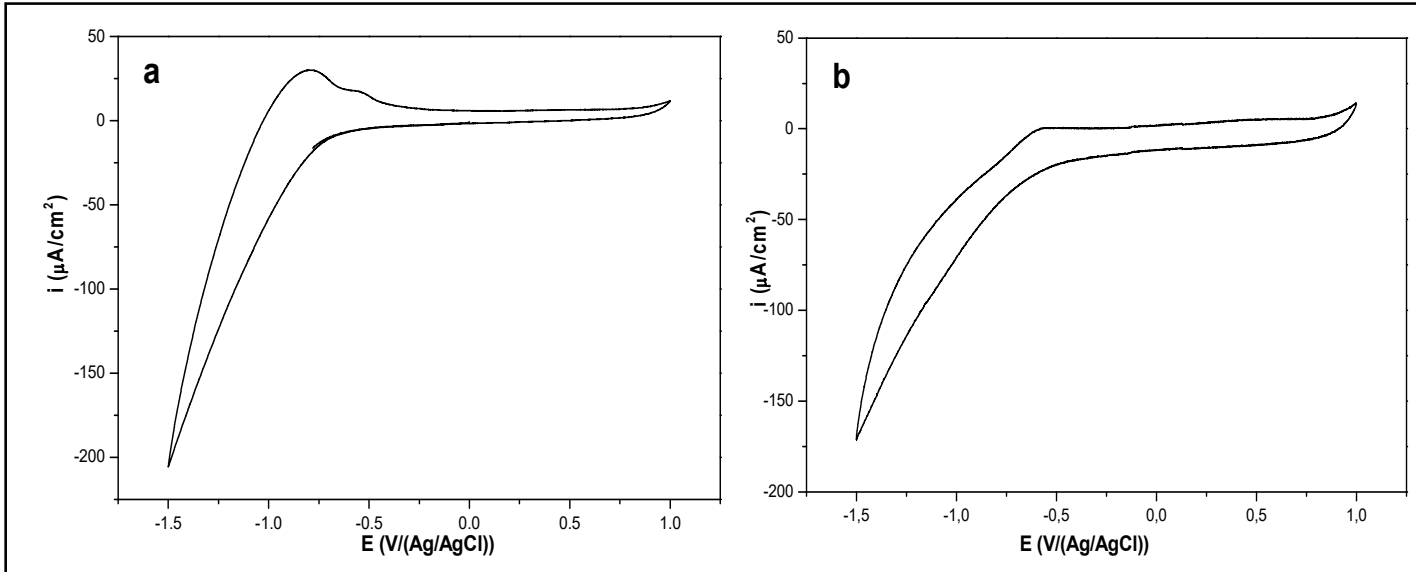

Figure 4. Cyclic voltamperogramms of titanium dioxide films deposited on FTO, in a $0.1 \mathrm{M} \mathrm{K}_{2} \mathrm{SO}_{4}$ solution, at $100 \mathrm{mV} / \mathrm{s}$ and $\mathrm{pH}=6.7$ : a) as-deposited film and b) heated film at $450^{\circ} \mathrm{C}$.

The cyclic voltamperograms present no significant currents at positive potentials, ca. $-0.2 \mathrm{~V}$ versus $\mathrm{Ag} / \mathrm{AgCl}$, as expected for an n-type semiconductor [27]. At potentials more negative than ca. $-0.2 \mathrm{~V}$ versus $\mathrm{Ag} / \mathrm{AgCl}$, a cathodic peak and an ill-defined anodic hump or peak were observed; the former corresponding to the reduction of $\operatorname{Ti}(4)$ species at the surface in contact with the electrolyte to $\operatorname{Ti}(3)$, and the latter to the re-oxidation process obtained during the positive potential surface scan of $\operatorname{Ti}(3)$ species, giving rise to a couple of conjugated cathodic and anodic peaks, characterized by an irreversible system [32-33].

We also can observe that the as-deposited titanium film produced higher current values than those from the heated deposit, in the potential range from -0.5 to -1.5 . The current of the as-deposited film is approximately 15 times higher than that corresponding to the heated film, which must be attributed to the high conductivity of the $\mathrm{OH}^{-}$of the as-deposited $\mathrm{TiO}(\mathrm{OH})_{2}$ film, on one hand, and to the decrease in the active surface site of the heated thin film, on the other. In the studied potential range, the hydrogen adsorption-desorption process also takes place [34-36].

\section{Catalyst tests}

Besides its use as acid-base indicator (changing color from red to yellow, in the $\mathrm{pH}$ range from 3.1 to 4.4), methyl orange is also used in textiles, food stuffs, pulp, and paper and leather industry. Methyl orange measurements obtained in function of mass concentration, using a spectrophotometer, are presented in Fig. 5. MO solutions varied in concentrations from 1 to $40 \mathrm{mg} / \mathrm{L}(1,5,10,25$ and 40 $\mathrm{mg} / \mathrm{L}$ ); they were prepared by dissolving MO powders in ultra-pure water. A 
maximum of absorbance was obtained at $\lambda=470 \mathrm{~nm}$, which increased with MO concentrations, presented in Figs. 5a to 5e. We can also observe a secondary absorbance peak at $290 \mathrm{~nm}$, which is less intense than the other [37].

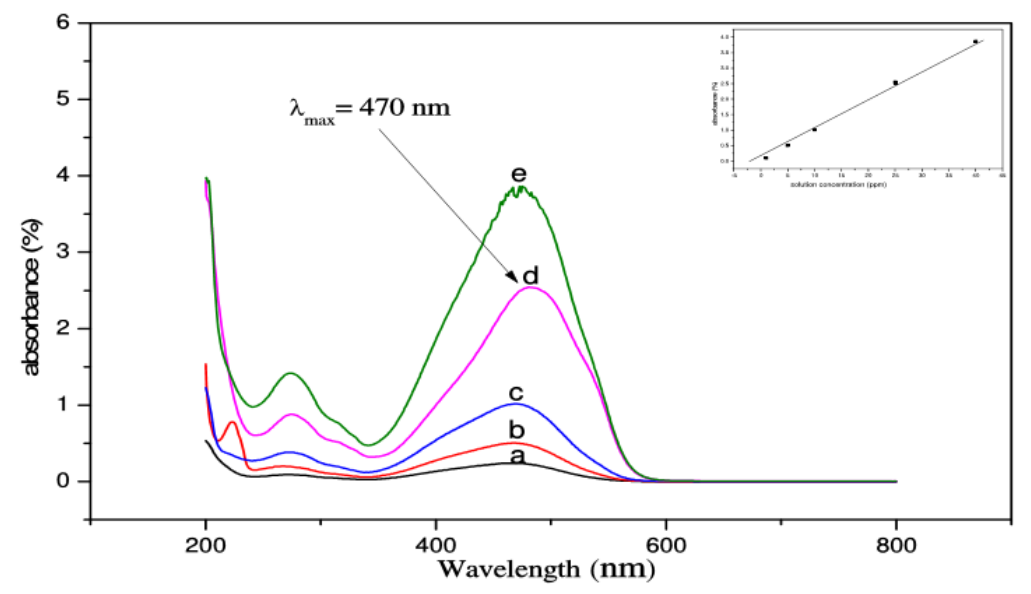

Figure 5. Absorbance spectra of: a) 1, b) 5, c) 10, d) 25 and e) $40 \mathrm{mg} / \mathrm{L}$ methyl orange solutions; inset, dependence of absorbance on the methyl orange solution concentration.

In order to follow the dye degradation rate under irradiation, we have carried out a series of absorbance measurements of methyl orange solutions (MO) with 10 ppm, under a UV lamp of $365 \mathrm{~nm}$, for a period which varied from $2 \mathrm{~h}$, at ambient temperature (about $25^{\circ} \mathrm{C}$ ), to $6 \mathrm{~h}$, without stirring, on a $\mathrm{TiO}_{2}$ surface film. The following results were obtained as a function of the solutions' mass concentration (Figs. $6 \mathrm{a}, \mathrm{b}, \mathrm{c}$ and d). For better visualization values, results are gathered in Table 1.

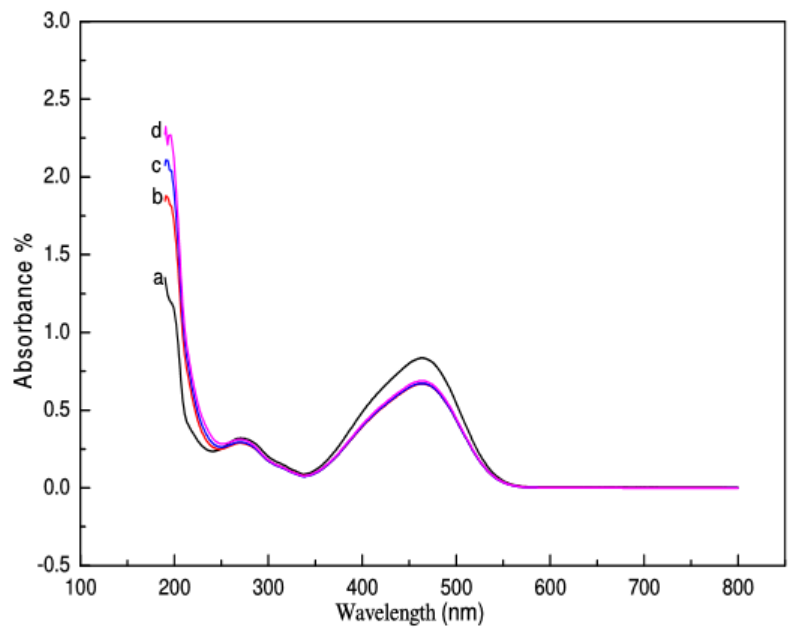

Figure 6. Methyl orange degradation rates at $10 \mathrm{mg} / \mathrm{L}$, under irradiation of a UV lamp with $365 \mathrm{~nm}$, from $0 \mathrm{~h}$ to $6 \mathrm{~h}$ : a) $0 \mathrm{~h}$, b) $2 \mathrm{~h}$, c) $4 \mathrm{~h}$ and d) $6 \mathrm{~h}$.

One can notice the decrease in the absorbance after $2 \mathrm{~h}$; then, a quasi-stability for $4 \mathrm{~h}$ and $6 \mathrm{~h}$. The decrease in absorbance intensities reveals the continuous dye degradation under increasing irradiation time. We also remark the increase in the absorbance intensity, in a regular way, with time, which leads us to say that one 
or more compounds were formed after MO degradation. In our case, we only have reached a partial degradation, as the whole absorption peak did not totally disappear. Maybe this is due to the small active area of our used photo catalyst. It is worth mentioning that, in all works, $\mathrm{TiO}_{2}$ has been used as a nano particulate powder, which possesses a high active adsorption surface. Nevertheless, these tests proved that photocatalytic degradation is an efficient way of dye removal from wastewaters, even with thin films, as also reported by [38].

Table 1. Variation of $\mathrm{MO}$ absorbance with immersion time, under irradiation, in $\mathrm{TiO}_{2}$ presence.

\begin{tabular}{cccc}
\hline $\begin{array}{c}\text { MO 10 mg/L } \\
\text { Irradiation time }\end{array}$ & $\begin{array}{c}\text { Wavelength } \\
\text { nm }\end{array}$ & Absorbance & \% \\
\hline $00 \mathrm{mn}$ & 463.5 & 0.834 & \\
$120 \mathrm{mn}$ & 463.5 & 0.669 & 19.7 \\
$240 \mathrm{mn}$ & 463.5 & 0.672 & 19.4 \\
$360 \mathrm{mn}$ & 463.5 & 0.689 & 17.3 \\
\hline
\end{tabular}

To better show $\mathrm{TiO}_{2}$ photo activity, we present, in Fig. 7, absorbances of several solutions comparatively measured. The first and the second are related to the 10 MO ppm solution; however, the second one underwent a series of cyclic voltamperograms (100 cycles), on non-irradiated carbon graphite, and the third one on a $\mathrm{TiO}_{2} / \mathrm{FTO}$ film obtained under darkness, during $30 \mathrm{~min}$. One could observe here a small decrease in the absorbance value obtained with carbon graphite and $\mathrm{TiO}_{2}$; nevertheless, these differences are not well marked; they highlight the fact that, even in the absence of irradiation, our $\mathrm{TiO}_{2}$ film presents a catalyzing effect, in spite of its low thickness, and of the small exposed active surface area.

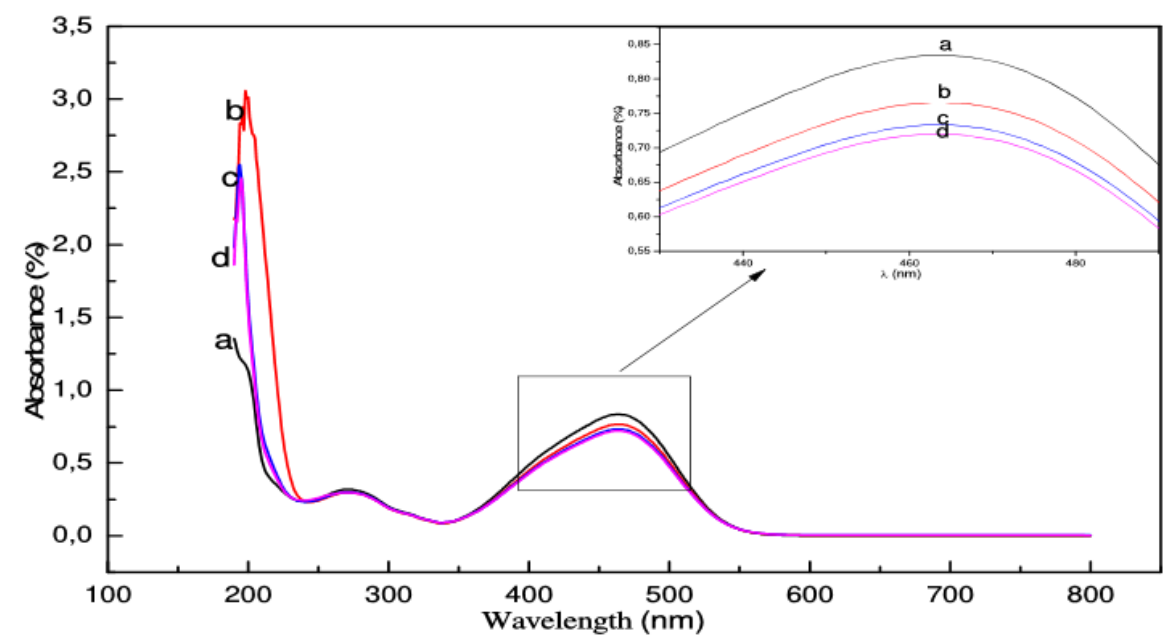

Figure 7. Absorbance spectra of : a) MO $10 \mathrm{ppm}$, b) after 100 cycle voltammetry on a graphite electrode under the dark, c) under the dark, for $30 \mathrm{~min}$, on a $\mathrm{TiO}_{2} / \mathrm{FTO}$ film and d) after 100 cycles. 


\section{Conclusion}

The electrodeposition route has been used to prepare nano-sized titanium dioxide on FTO, from a peroxo-titanium solution. The X-ray diffraction (XRD) shows that the as-deposited film was amorphous, and that the heat-treated film presented a crystalline anatase structure. The scanning electron microscopy (SEM) and atomic force microscopy (AFM) showed the homogeneity and little roughness of the films. The electrochemical behavior of such films shows the characteristic irreversible system, and more electric activity of the as-deposited titanium (non-heated) films, which can be attributed to their high $\mathrm{OH}$ conductivity. The tests of such films as photo catalysts gave good results by Spectro photochemical measurements; we have observed partial dye degradation on the $\mathrm{TiO}_{2}$ photocatalyst surface under illumination, and little decomposition also under the dark. The absorbance intensity decreased more in $\mathrm{TiO}_{2}$ presence than in that of carbon graphite. Such tests prove the value of electrodeposited $\mathrm{TiO}_{2}$ as a photo catalyst for dyes degradation.

\section{Acknowledgment}

The authors are indebted to the University of Setif 1 (UFAS), who provided financial support for the conduct of this research.

\section{References}

1. Carp O, Huisman CL, Reller A. Photoinduced reactivity of titanium dioxide. Prog Solid State Chem. 2004;32:33.

2. Grätzel M. Solar Energy Conversion by Dye-Sensitized Photovoltaic Cells. Inorg Chem. 2005;44:6841.

3. Longo C, De Paoli M-A. Dye-sensitized solar cells: a successful combination of materials. J Braz Chem Soc. 2003;14:898.

4. Akpan UG, Hameed BH. Parameters affecting the photocatalytic degradation of dyes using $\mathrm{TiO}_{2}$-based photocatalysts: A review. J Hazard Mater. 2009; $170: 520$.

5. Kar A, Smith YR, Subramanian V (Ravi). Improved Photocatalytic Degradation of Textile Dye Using Titanium Dioxide Nanotubes Formed Over Titanium Wires. Environ Sci Technol. 2009;43:3260.

6. Mahmoodi NM, Arami M. Degradation and toxicity reduction of textile wastewater using immobilized titania nanophotocatalysis. J Photochem Photobiol B Biol. 2009;94:20.

7. Wesenberg D, Kyriakides I, Agathos SN. White-rot fungi and their enzymes for the treatment of industrial dye effluents. In: Biotechnology Advances. 2003. p 161.

8. Honda $\mathrm{H}$, Ishizaki A, Soma $\mathrm{R}$, et al. Application of photocatalytic reactions caused by $\mathrm{TiO}_{2}$ film to improve the maintenance factor of lighting systems. $\mathrm{J}$ Illum Eng Soc. 1998;27:42.

9. Linsebigler AL, Lu G, Yates JT. Photocatalysis on $\mathrm{TiO}_{2}$ Surfaces: Principles, Mechanisms, and Selected Results. Chem Rev. 1995;95:735. 
10. Stewart G, Fox MA. The effect of dark recovery time on the photoefficiency of heterogeneous photocatalysis by $\mathrm{TiO}_{2}$ suspended in non-aqueous media. Res Chem Intermed. 1995;21:933.

11. Rashed MN, El-Amin AA. Int J Phys Sci. 2007;2:73.

12. Chatterjee D, Mahata A. Demineralization of organic pollutants on the dye modified $\mathrm{TiO}_{2}$ semiconductor particulate system using visible light. Appl Catal B Environ. 2001;33:119.

13. Chatterjee D, Dasgupta S. Visible light induced photocatalytic degradation of organic pollutants. J Photochem Photobiol C Photochem Rev. 2005;6:186.

14. Kiriakidou F, Kondarides DI, Verykios XE. The effect of operational parameters and $\mathrm{TiO}_{2}$-doping on the photocatalytic degradation of azo-dyes. Catal Today. 1999;54:119.

15. Konstantinou IK, Albanis $\mathrm{TA}$. $\mathrm{TiO}_{2}$-assisted photocatalytic degradation of azo dyes in aqueous solution: kinetic and mechanistic investigations: A review. Appl Catal B Environ. 2004;49:1.

16. Gonçalves MST, Oliveira-Campos AMF, Pinto EMMS, et al. Photochemical treatment of solutions of azo dyes containing $\mathrm{TiO}_{2}$. Chemosphere. 1999;39:781.

17. Wang G-S, Liao C-H, Wu F-J. Photodegradation of humic acids in the presence of hydrogen peroxide. Chemosphere. 2001;42:379.

18. Karuppuchamy S, Jeong JM. Super-hydrophilic amorphous titanium dioxide thin film deposited by cathodic electrodeposition. Mater Chem Phys. 2005;93:251.

19. Zhitomirsky I. Cathodic electrosynthesis of titania films and powders. Nanostructured Mater. 1997;8:521.

20. Zhitomirsky I, Kohn A, Gal-Or L. Cathodic electrosynthesis of PZT films. Mater Lett. 1995;25:223.

21. Ge L, Xu M, Sun M, et al. Fabrication and characterization of nano $\mathrm{TiO}_{2}$ thin films at low temperature. Mater Res Bull. 2006;41:1596.

22. Karn RK, Srivastava ON. On the synthesis of nanostructured $\mathrm{TiO}_{2}$ anatase phase and the development of the photoelectrochemical solar cell. Int J Hyd Energy. 1999;24:27.

23. Saini KK, Sharma SD, Chanderkant, et al. Structural and optical properties of $\mathrm{TiO}_{2}$ thin films derived by sol-gel dip coating process. J Non Cryst Solids. 2007;353:2469.

24. An H-J, Jang S-R, Vittal R, et al. Cationic surfactant promoted reductive electrodeposition of nanocrystalline anatase $\mathrm{TiO}_{2}$ for application to dyesensitized solar cells. Electrochim Acta. 2005;50:2713.

25. Karuppuchamy S, Iwasaki M, Minoura H. Electrochemical properties of electrosynthesized $\mathrm{TiO}_{2}$ thin films. Appl Surf Sci. 2006;253:2924.

26. Georgieva J, Armyanov S, Valova E, et al. Preparation and photoelectrochemical characterisation of electrosynthesised titanium dioxide deposits on stainless steel substrates. Electrochim Acta. 2006;51:2076.

27. Chettah H, Abdi D, Amardjia H, et al. Electrosynthesis of $\mathrm{TiO}_{2}$ oxide film on ITO substrate and electrochemical comparative study of the oxide with its hydrated gel. Ionics. 2009;15:169. 
28. Hachisu T, Shi K, Yokoshima T, et al. Preparation of anatase phase titanium dioxide film by non-aqueous electrodeposition. Electrochem Comm. 2016;65:5.

29. Miyake M, Takahashi A, Hirato T. Electrodeposition and Anodization of Al$\mathrm{TiO}_{2}$ Composite Coatings for Enhanced Photocatalytic Activity. Int J Electrochem Sci. 2017;12:2344.

30. Natarajan C, Nogami G. Cathodic Electrodeposition of Nanocrystalline Titanium Dioxide Thin Films. J Electrochem Soc. 1996;143:1547.

31. Kontos AI, Kontos AG, Tsoukleris DS, et al. Superhydrophilicity and photocatalytic property of nanocrystalline titania sol-gel films. Thin Solid Films. 2007;515:7370.

32. Utomo WB, Donne SW. Electrochemical behaviour of titanium in $\mathrm{H}_{2} \mathrm{SO}_{4}-$ $\mathrm{MnSO}_{4}$ electrolytes. Electrochim Acta. 2006;51:3338.

33. Hayden BE, Malevich DV, Pletcher D. Electrode coatings from sprayed titanium dioxide nanoparticles - Behaviour in $\mathrm{NaOH}$ solutions. Electrochem commun. 2001;3:390.

34. Karuppuchamy S, Iwasaki M, Minoura H. Electrochemical properties of electrosynthesized $\mathrm{TiO}_{2}$ thin films. Appl Surf Sci. 2006253:2924.

35. Georgieva J, Armyanov S, Valova E, et al. Photoelectrochemical behaviour of electrodeposited tungsten trioxide and electrosynthesised titanium dioxide single component and bilayer coatings on stainless steel substrates. J Electroanal Chem. 2005;585:35.

36. Zhang J, Yang $\mathrm{C}$, Chang $\mathrm{G}$, et al. Voltammetric behavior of $\mathrm{TiO}_{2}$ films on graphite electrodes prepared by liquid phase deposition. Mater Chem Phys. 2004;88:398.

37. Meng F. Photocatalytic degradation of methyl orange by nano- $\mathrm{TiO}_{2}$ thin films prepared by RF magnetron sputtering. Chinese Opt Lett. 2009;7:956.

38. Du Y-B, Zhang L, Ruan M, et al. Template-free synthesis of threedimensional porous $\mathrm{CdS} / \mathrm{TiO}_{2}$ with high stability and excellent visible photocatalytic activity. Mater Chem Phys. 2018;212:69. . 